\title{
Conceptualizing Assimilation of Interactional Justice within Social Justice Ethical Code Application as Exemplified at Imo State, Nigeria: Widowhood and Inheritance Challenges
}

\author{
Nwachukwu, Precious Tobechukwu Toby \\ University of Zululand, Private Bag X1001, Kwa-Dlangezwa, 3886 \\ Email: precioustoby@yahoo.com or tobynwachuks@gmail.com
}

Doi:10.5901/mjss.2014.v5n23p2137

\begin{abstract}
The article explores and discusses the role of assimilating interactional justice within the concept of social justice approach to ethical code application. The literature review and theoretical dimension to the study reconnoitered the Social Exchange and the General Strain theories as they relates to interactional justice perspective and deliberates on the impact of three social justice aspects from their outcome-oriented and relationship-oriented paradigm to the study and its apparent implications to the ethical code. This study's appraisal investigated application of interactional justice amid social justice ethical views, experiences and attitudes of social workers that where extracted from a qualitative focus group discussion study design of ( $n$ 33) practitioners in Imo State based on the socio-cultural patterns of the people that have been sources of dilemma in advocating for social justice. Recommendations were made including five possible areas on how practitioners could be prepared to address the social and cultural discrepancies pertaining to advocacy of social justice within interactional justice application as well as future study engagement on administrators-practitioners relationship outcome to policies regulations.
\end{abstract}

Keywords: Practitioners, Social justice, Ethical code, Interactional justice, Relationship-oriented, Outcome-oriented, Widow-hood, Cultural practices, Inheritance

\section{Introduction and Study Background}

The contextual ideology of social justice portrays acting justly in fairness accrue through "patterns of ideal benefits from social cooperation and distribution of fundamental rights and duties from social institutions" designed for a healthy arranged society (Rawls, 1971:6-8). It illustrates such stance of well-organized society, as Rawls envisaged that it represents persons performing fairly to a beneficially contented society where public utilities efficiently run to assist every person (Clayton and Williams, 2004; Bankston, 2010). Social justice has concomitant within equity theory paradigm exploring exchange outputs within organisational analysis dialogs (Glass and Wood, 1996:191).

Social justice treatise notion by Young (2006:102) involves social connectivity of responsibility and governance even political processes, others allied the phenomenon with social inclusion, accessibility and redress of inequality, social and cultural sustainability and diversity (Vallace, Perking and Dixon, 2011; Farrington and Farrington, 2005:5-7; Soini and Birkeland, 2014:214). Dissevering through culture illustrates the underpinning intended for specifying the goals on outlook in identifying socio-economic and ecological sustainability interpreted by discourses analysis and storylines structures (Hajer, 2005; Soini and Birkeland, 2014:215). Narratives are aptly concepts, ideas in establishing and conserving meaning, assembling a problem in a specific manner. Therefore, social justice can be elucidated in three different dimensions within commercial, collective and traditional aspect of societal wellbeing.

United Nations and International Labour Organisation (ILO) policies demeanor concerning the World Day of Social Justice celebration on the 20th February, 2013 defined attests to their obligatory commitment to social justice for a fair globalisation and advancing social justice through policies influencing constitutional objectives. Social justice advocacy by practitioners must engage an 'organized focused system towards guarding, epitomizing the welfare of customers' systems, utilise a self-reflexivity approach to aid bequeath restoration of justice for the oppressed and disadvantaged persons in the society and aim to comprehend social structures in relation to power and obstacles that assist in perpetuating inequalities and injustices" (Jonsson, 2010:404; Hoefer, 2006:8). The onus by virtues of one's social role, especially as a social worker has the responsibility "to discourage or redeem injustice in contrast to the blame and liability ordinary concepts of responsibility within law aspect" (Young, 2006:119).

This implies that social workers must be aware of the intricacies and subtle social justice violations that may arise within the rights of people, be it the perceived cultural or social rights of citizens even within immigrants concerns therein. 
Literatures on social justice reveal three components of namely distributive, procedural and interactional and have extensively gathered important relationships between these divergent aspects of social justice and clientage services especially in the economics and marketing field (Clemmer and Schneider, 1996; Marti'Nez-Tur, Peiro, Ramos and Moliner, 2006:102; Oliver and Swan, 1989a, 1989b). Researchers have deliberated on social justice within individual's aspect of publicly valued provisions and resources that were justifiably and equitably dispersed, linking the "queuing perspective" as a rationalization of a well-arranged society (Zajda, Majhanovich, and Rust, 2006:2; Larson 1987:896). Studies have linked social justice with perceptions to customer experiences, expectations of outcomes or unfair procedures and customer satisfaction (Oliver and Swan, 1989a, 1989b). Others have linked social justice concepts with fairness and judgments, truthfulness and respect during communication and decision-making procedures, linking social justice to mediatory role of trust in organisation and work outcomes (Ladebo, Awotunde and Abdulsalaam-Saghir, 2008; Aryee, Budhwar, and Chen, 2002: 268). Generally, people are sanguinely assured that social justice are permeated interiorly on the idea that all persons have equal opportunity to access and get the required value from the society as well as ensuring smooth running of governmental services of all.

In the field of economics, management and marketing, the dominant aspect of social justice has been on the distributive justice and procedural justice, these lingered areas exposed by the amount of literatures that researchers had keen interest by investigating on consumer behaviour, employer-employee relationship (Marti'Nez-Tur et al, 2006: 103; Cropanzano, Rupp, Mohler, \& Schminke, 2001; Clemmer \& Schneider, 1996; Oliver \& Swan, 1989a, 1989b). Interactional justice is more of "relationship-oriented" and has been denoted as the idea of "perceptive quality of treatment" experienced in a work place that bestowed on an employee (Clemmer and Schneider, 1996; Oliver and Swan, 1989a, 1989b). It is derived from applying procedural policies or how employees perceive their treatment by "authority figures" (Greenberg, 1990). Studies have defined it as the "employee-employer relationship" where all members anticipates fairness, honesty, dignified respect can be accounted for in the work place (Ladebo et al, 2008: 206). Researchers have found out that customers react negatively when they experience unfair procedures or treatment, thus evolving a justice motive and judgmental attitudes towards the organisation and their employees (Marti'Nez-Tur et al, 2006; Clemmer and Schneider, 1996).

\subsection{Challenges}

There is stagnation of literature pertaining to interactional justice paradigm in the fields of Social Work practice milieu, where social justice ethic is attributed as the pillar of the profession enshrined in the Ethics of Code (SACSSP, 2005:5). In service peculiarities, interactional justice denotes to the impartiality of the interpersonal handling of what clients get throughout their consumption involvement with the service firms, as well as related to the 'further interpersonal matters of procedural engagement such as being polite and empathic' (Marti'Nez-Tur et al, 2006:105; Clemmer \& Schneider, 1996; Blodgett et al, 1997). The role of interactional justice cannot be sidestepped due to the fact that it encompass "relationship-oriented" with its stronger ties with procedural justice as both deal with relationship between "employeremployee," in contrast to distributive justice that is based on "outcome-oriented" which most studies had focused on. Thus, the tranquil posture of social work researchers to interactional justice presages vulnerability to practice. Disadvantaged persons experiencing alienation and trepidation can be entombed, if practitioners exhibit any atomistic gleam of interactional injustice.

Ascertaining the "socio-emotional bond between connecting workers and customers, as in a usual service situation are always transitory, as most clients would be favorably disposed to satisfaction derived from consumption experience," lending to outcome-orientation (Marti'Nez-Tur et al, 2006:109). Social emotional bond values, interpersonal issues via social interactions and consumption quintiles may offer more "predictive power" as relationship between practitioners and clients relationship increase (Marti'Nez-Tur et al, 2006:112). Nevertheless, considering the "abstraction level" of outcomeoriented (distributive justice) and relationship-oriented (interactional/procedural justice) amid research from the economics and marketing fields are based on the notion that most interactions between employees and customers were revealed to be "brief'(Ladebo et al, 2008; Marti'Nez-Tur et al, 2006: 114; Clemmer \& Schneider, 1996).

The field of Social Work with its roots on interpersonal relationship and optimizing clients' recovery to social functioning would not likely treat clients with "abstraction" in view of social justice ethic, but rather will advocate for social justice utilisation contained in the operational ethical code. It has a significant bond with clients' need, where clients would be given ample time to disclose their inner feelings rather than been "brief," respect interpersonal rapport, where empathy, patience and boundary maintenance are the prerequisite for an efficacious Social work practice. 


\section{Theoretical Dimension}

Social justice theoretical dimension relates from the Social Exchange theory of Blau (1964:91-92). He termed it to the 'envisioned activities of people that are driven through the proceeds requisitely anticipated to convey, also routinely fixed and derives from others'...thus denoting long-standing interchange of favour that prevents the keeping of records which is centered on a prolix duty to respond. In the economic perspective, social exchange unveils the lawful authorizations requisites within an officially recognised contract covering the precise amounts, detailed for exchanged and the benefit exchange which designates reciprocal support and venture in the association (Marti'Nez-Tur et al, 2006:103-4; Aryee et al, 2002:268).

In the social context, social exchange model theoretical dimension link to work attitudes and behaviours that account for mutual support and relationship investing between administrators and practitioners as well as practitioners and their clients (Wayne, Shore and Liden, 1997; Clemmer and Schneider, 1996). The functioning mode of the service been conveyed have to pay more attention to the procedural justice aspect depicted as the "methods applied to reach at the outcome," accessibility and operative (Blodgett, Hill, and Tax, 1997; Thibaut and Walker, 1975). Interactional justice deals with more on interaction with practitioners and accompanied by interpersonal rapport of social justice not necessarily the attained speed and access (Cropanzano et al, 2001; Colquitt, 2001; Clemmer \& Schneider, 1996).

This portrays the expected role-relationship plays in social exchange such as "socio-emotional value," considering dignity and respect for the worth of person, status perceptions by interacts (Cropanzano et al, 2001), attention, empathy, appreciation, warmth. The understanding illustrates that people do not envisaged to be treated in abstraction or like goods; as such clients can perceive if they had been treated unjustly. Uncertainty pertaining to delays and postponements of their needed services without adequate explanations or no sympathetic reflexive compassion from practitioners can be easily detected.

The General Strain Theory (GST) propagation of (Scheuerman, 2013; Agnew, 2006) have its roots from the criminal justice which involves interactional justice dealing within processes of contact among social workers as well as their clients and also their employed agencies interrelatedness. Interactional justice within the General Strain theory is based on the premise that perceived injustice motivates negative emotions which lead to anger and criminal acts, that injustice could be derived from "unfair outcomes" (distributive injustice). It also refers to unfair processes utilised in deciding the outcome (procedural injustice) and witness of partial treatment -inconsiderate, discourteous or belligerent (interactional injustice) within the practice milieu.

In application to social work practice, interactional injustice emanates from new organisational policies of pruning budget with more commercialised outlook, thereby suppressing the humanitarian core value inherent in Social Work (Harrison and Pierpont, 2006:4; Forde and Lynch, 2013:1-2). Intrinsically, clients might perceive current carriage as unfair treatment; practitioners can now apply interactional justice to efficaciously cogitate the situational dilemma.

\section{Appraising Social Justice Ethical Code on Practitioners' Obligation}

Rodgers (2009) supports the idea of global Social work to embrace practice of an inclusive individual's comprehensive welfare. He tasks social workers to investigate if their national codes of ethics uphold the value of social justice implementation and proffer ways to curb ineffectiveness of the codes in tackling defects on promoting social justice and human rights. Harrison and Pierpont (2006:3) analysed effects of siege on social justice ethic for practitioners, argue that a "solid opposing ideological and cultural forces" poses a threat to the ethical outlining of daily practice of social workers in a "form of "atomistic job designs," practice prescriptions that focuses on results, and displays of global, corporate bureaucratic philosophy. They assert that practitioners should seek ways of "strengthening the pursuit of social justice" through critical examination of "political theory as a foundation for social workers" and coalition with disadvantaged and unjustly treated people.

Nevertheless, how can social workers both in administrative capacity and those employed under non-social work or social work agencies utilise the admonition by Harrison and Pierpont to brace the odds and champion the course of sustaining the social justice ethic? Convincingly, Marti'Nez-Tur et al (2006:113) in their study affirm that further research should engage on how 'managers should seek avenues to empower their staff to treat clients effectively in an efficient serviceable and interpersonal rapports, as well as recompense plans, detailed preparation, work sketch, that would ensure excellent service linkages to interactional and procedural viewpoints.' Furthermore, researchers have argued that organisational practices and "attitudes of authority figures" in interactional justice perspectives on fairness to their employees have a role in staff work attitude and behaviour; that supervisors are most responsible for unjust treatment in the office, that researchers most times do not differentiate amid level of unjust treatment by superiors and subordinates 
(Ladebo et al, 2008; Colquitt et al, 2001).

These studies have shown the vital need for authority personnel in influencing interactional injustice through policies enhancement. Social workers have to apt their craft to stop the "siege against the social justice ethic" (Harrison and Pierpont, 2006:3-5) which is the one of the foremost powerful value and principle that makes the Social Work profession outstanding from other helping profession such as Law (Vandervort et al, 2007). Forde and Lynch (2013:2) reasoned that on-going reform should stress on decreasing the bureaucratic restrictions for social workers. They recommend employing agencies should prioritise on the "principle-based" value for social workers within relationshiporiented practice although having outlook of "outcome-oriented" business-types. The need to cut expenses should not erode the interpersonal, socio-emotive and intrinsic interactional values which interactional justice is based on, and its duty bond for social workers to adhere to as stipulated in their professional code.

\subsection{The Effects of Applying Interactional Justice to the Ethic Social Justice}

Interactional injustice as decoy to social justice (General Strain theory), can erode the individual concept that leads to straining emotional experience, bitterness, disgust, resentment and anxiety (Agnew, 2006, Stecher and Rosse, 2005). Disrespectful or belligerent are the components that depicts interactional injustice, yet, it could be worrisome if practitioners engage in interactional injustice to appease their employers' policy approaches to service conveyance to the detriment of advocating for social justice.

Section 4.1 of the SACSSP (2005:5) code of ethics portrays social justice as the pinnacle of social work practice commitment in enabling disadvantaged persons, groups, families and communities to utilise their efforts to combat matters regarding unemployment, poverty, discrimination and any forms of social injustice. It addresses political beliefs, influence of political arena, equality in assessing employment, resources, opportunity, advocacy for policy changes and legislation, gender identity and immigration status to show the distinctiveness of Codes in enunciating ethical responsibilities (Buila, 2010). Hypothesising that barriers people face especially in ensuring equity should be removed, practitioners must "understand the impact of powerlessness" (Calma, Baldry, Briskman, \& Disney (2011:2-3) while engaging with persons from varied contextual upbringing, as participation transpose inclusion of new cultural groups to express their needs, matters, anxieties and reservations and give their input on operations of the organisation. This obligates 'social workers to apply sensitivity and insightfulness concerning cultural and ethnic diversity through making sure that certain information, resources, services do not elude any persons in the communities.

\subsection{Social Justice Appraisal within Cultural Practices: Widowhood and Inheritance}

Interactional injustice permeates into cultural norms and values, some cultures tolerate several dehumanizing of widows during mourning period. In Africa, the disproportionate parallel between widowhood and widowerhood in Nigeria has great contrast as the males enjoy less burdensome rites of mourning than the females (Basden in Afigbo, 1989: 8-9). He wrote that mourning is characterised by the "traditional religious rites involving an era of hardship and deprivation, different notches of physical isolation and a condition of ritual contamination and purification at the end of the process which are also infused by its Christian and Islam infusion."

In contemporary epoch, practices dehumanizing widows such as wearing rags or specific clothing, wailing continuously, desisted from bathing still permeate the cultural lexicon of some areas in Imo State, a part of Igbo speaking area which is a highly patriarchal society. The Gender and Equal Opportunity Law of 2007, Section 8 directs "agency, body, organ, public institution, authority etc. to be involved in the modification of the social and cultural designs of the people with the notion of attainment of eliminating prejudice and customary and other practices based on stereotypes roles for males and females and perceived superiority of sexes"(Gender Equity, 2007:8). Furthermore, it stipulates in Section 21 on "Rights to inheritance of family benefits, on how widows should not be deprived of remaining abode in her husband house and not to be subjected to inhuman, humiliating or degrading treatment etc." (Gender Equity, 2007:2021). Furthermore, Constitutional rights of women in Section 43 of the Nigerian Constitution authoritised men and women to possess and purchase removable and fixed property, yet many women in Nigeria are disfranchised from this privilege due to customary laws pertaining to inheritance (National Gender Policy, 2006:3). However, evidence emanating from this article's research revealed a complete defiance in contrast to these laws as communities were still practicing the dehumanizing of individuals due to some cultural ideologies. 


\subsection{Practitioners' Constructiveness of Interactional Justice}

Under the circumstances of providing clients with effective and efficient social work services, rights of clients should not infringe on by others. We belong to the human race and are mirrored as moral agents who have the ability to form our own individual ventures and pursuing means to realise them continually as we live (Ward and Birgden, 2007:630). The focus on constructive social interaction as a prelude to curbing injustice can be reflective on the impact role of interactional justice application within all spheres of practitioners' engagement with clients can have a positive effect on "outcome-oriented" but most especially on "relationship-oriented" service conveyances. Practitioners need to dig deep on the area of awareness of their clients' types in respect to organisational policy and its effect on clients.

\section{Study Backgrounds and Methods}

\subsection{Research Design}

The study embraces a qualitative design approach, which rationalised to eliciting the feelings, attitudes and behaviours of social work practitioners in the remote bucolic settings on their views on social justice. The adaptation of this design is appropriate by way of its expediting the consideration of the process within the context of presenting on interactional justice and its operational challenges to social and cultural patterns experienced by social workers than its outcome. A qualitative exploratory study seeking to confirm several issues that are frazzled in the review of literature happening within the phenomena (Gross, Alba, Glass, Schellenberg and Obrist, 2012). Furthermore, discourse analysis (Soini and Birkeland, 2014:215-216) will provide expedient facet of unmasking of a "precise problem that permeates cultural practices justification expected to explain, how the problem is framed and in what way the solutions are planned in society, in policy and in practice." Qualitative procedures contribute to an inclusive knowledge (Simmons and Rycraft, 2010) of practitioners' experiences on ethical concerns on bucolic practice domain as well as utilising participant observation to capture the situation of the study phenomenon.

\subsection{Research Instruments and Study Domain}

The study used structured open-ended interviews based on fundamental questions concerning Social work ethical principle-valued standard executed for gathering of data. It brought about uniformity in the questions seeked for and intended at standardizing the data gleaned from all respondents through a face-to-face interview which was performed with 8 focus group discussions (FGDs) of practitioners assigned to the researcher from selected units in Owerri, Ngor Okpala, Aboh Mbaise, Njaba, Okigwe, Isiala Mbano and Ehime Local Government Areas. Three senatorial zones of the state were investigated during the observational tours of designated areas for community profiling. Imo state of Nigeria is a homogenous entity, the name is derived from the Imo River, located at the South-eastern region of country and has a population estimate of 3,934, 899 as of the 2006 census (National Bureau of Statistics of Nigeria, 2007). Testing of the instrument and refinements preceded the study and the administrators in each of the designated study areas supervised the respondents.

\subsection{Sampling Procedure}

In the proper sampling and gathering of data for this study, the researcher created a good rapport with the participants and questions were asked by participants as they fill-up their demographic data. Practitioners involved in the focus group discussions were assigned to engage the researcher on job-trailing which is a part of participant observation as this research was conducted in July to September, 2012 during the cultural August day celebrations in Imo State. The focus group discussions accelerates the gleaning of qualitative data on views, feelings, attitudes and behaviours of social work practitioners on the challenges pertaining to interactional justice application and ethical code adherence. The researcher witness firsthand the interaction between social workers and their clients in the practice milieu as clients came to report matters and seek guidance on services. The senior social workers formed the component of the analysis and their selection criteria and grouping where based from their service stations, also it was free from bias relating to gender, age etc. (Kang'ethe, 2011: 61). Questioning, observations, reflective participatory discussions and remarks were audio-taped and at the same time written down by the researcher and deleted after data analysis (Richter and Mlambo, 2005) to conform to the ethical informed consent. 


\subsection{Ethical and Legal Considerations}

The study ethical reflection centered on privacy, anonymity and the choice to participate and freedom to exit during focus group interview sessions without any penalties (Neuman, 2006) and the deleting of audiotapes after analysis (Richter and Mlambo, 2005) and the informed consent for each participants were given before the commencement of the study. The vetting by University of Zululand Research Committee with the registration of the project No (S752/11) and the a letter written by the researcher to conduct the study to the Imo State Ministry of Women Affairs and Social Development, Owerri seeking approval commencing this study. Authorization letters by the Permanent Secretary of the Ministry and its Head of the Social Welfare Unit organized informed data of managers in the zones and local government areas facilitated the smooth conducting of this research.

\subsection{Data Analysis and Interpretation}

The focus group interview schedule lasted between forty-five to an hour period was documented during discussions which was translated into English from Igbo language, audio-taped and transcribed. Data gleaned during the course of this study was presented through fitting tabular means and graphs. The data analysis was designed to create frequencies and correlations of the study findings through the descriptive analysis of the data clued from qualitative design. Thematic analyses of interviews were performed as theme descriptions were revised towards re-categorizing specific sections of the manuscript with the foremost theme identified through their frequency and their degree of close association in denotation and discourse with other themes in the text. Research assistants comprising research fellows and computer analysts assisted in ciphering the independent codes, reduction of data and interpretations and safeguarding uniformity of coding (Simmons and Rycraft, 2010).

\section{Findings of the Study}

\subsection{Respondents' Profile}

The respondents were social work practitioners (n-33) at 8 out of the 27 local government areas of the state, (21.2\%) were males and females (78.8\%); while the educational attainment reveal $(87.9 \%)$ have the required degree for social work practice and (12.1\%) having additional degrees relative to the field. The age range of respondents reveals that majority was 41 years and above (66.7\%), followed by practitioners between 31-40 years (27.3\%) and 20-30 year olds (26.1\%). Respondents' numbers of years in practice reveals that those with 6-10 years of practice experience were (39.4\%), those with 10 years and above were (24.2\%) and those with 0-5 years were (36.4\%). In their practice settings, respondents that work with the Ministry of Women Affairs and Social Development Department were majority with (72.7\%), those that work with NGOs were (9.1\%), School (9.1\%) and those that work in the Hospital accounts (9.1\%).

\subsection{Respondents' Definitions on Social Justice Application to Ensure Equality}

On Social justice, what are your suggestions to ensure fair access to assets, facilities and opportunity to addressing basic human needs? Respondents provided solutions and ideas on how to ensure essentials human needs within the ethical standard of Social Justice. The replies from the discussions that were recurrently captured exhibit the followings:

Utilising community-oriented methods to access resources/ensuring ruralness approach/Equal distribution.

Prioritising needy ones in practice service and ensuring volunteerism.... Working with community leaders.... Constant consultation

Formation of peripatetic day for each community and assigning a social worker for each ward.

Generally, it was apparent that practitioners have to create time advocating for social justice with equitably perspective in mind and ensuring the ruralness approach. The social exchange theory in relating to social justice is more noticeable here as practitioners liaise with community leaders in sharing of awareness for common goal.

\subsection{Upholding Social Justice and Respect for Worth and Dignity of Persons}

"The OSU caste system (outcastes practice) is still prevalent.... this type of social stratification is severe...highly 
controversial and delicate within some communities and concomitant interactions among people in marriage relationship and family ties... often disfranchising the social justice ethic during customary engagements among the people."

"The lexicology of child out-of-wedlock is not encouraged in our culture, yet we have ensure human dignity and rights... the situation creates sufferings for the child...the child is not allowed to inherit the mother's property by h/her uncles and considered as a pariah.....irrespective that both parents could have married later.....widowhood and girl-child inheritance are major concerns here even though there are laws that prohibit such practices, yet it persists."

This indicates a disheartening state of affairs on cultural practices at the study area including the aversion to caste system on children's rights as well as women's rights that have impeded on dignity and worth of a person and human rights (Buila, 2010). Female inheritance issue has always been a problem in the mainstream patriarchal cultures especially in the South-Eastern part of Nigeria, thus the involvement of practitioners are on high alert to ensure social justice ethic. Practitioners' concern of the state of affairs depicts the social justice theoretical link on interactional justice via General Strain theory (Scheuerman, 2013) which asserts that when processes to ensure social justice are flawed (Agnew, 2006; Colquitt, Greenberg and Zapata-Phelan, 2005) that social workers need to fight for the upholding of social justice.

\title{
5.4 Relating Interactional Justice to Ethical Code Adherence
}

Majority of the respondents complained that there are lack of family courts here in the rural areas of Imo State and most of the cases that are based on family issues are been handled by the customary courts. The customary courts being custodians of the social and cultural customs of the people would judge and treat these cases within the local customs which are the actual interferences to the advocating of social justice. The following were the responses:

\begin{abstract}
"The traditional rites of "Iwakwa festival" (denotes attainment of manhood in Mbano)...a young man was denied participation because the mother had him out-of-wedlock....the traditional chiefs still insist on excluding him from partaking, often it could lead to ostracizing the client...we intervened for the client to challenge the decision....we endorsed the social justice ethic during therapeutic sessions with clients, we ensure emphatic hearing and compassionate understanding explaining the options for him.

"The customary courts oversees cases that are supposed to be addressed at the family courts thereby denying clients their voice on intrinsic family concerns...most times clients are not satisfy with the outcomes from customary courts as the courts hold on to cultural practices...but we help them to get their cases redress at the higher courts to restore their rights to their properties and dignity as obligated for the social justice ethic...during interactive sessions we keep the discussion professional not to offend individuals linked to such problems or caste system, they can discern if you discriminate or seem to support such cultural norms against them."
\end{abstract}

There is a cursor of the meticulous adherence of relating interactional justice by the practitioners, as clients are not rushed to make hasty decisions but attending to each client's needs with peculiarity to their desires and situations. Here, the social exchange theory in relating to interactional justice are evident as interpersonal contact with the practitioner is not "brief" or in "abstraction as goods" (Ladebo et al, 2008, Marti'Nez-Tur et al, 2006), but reasonably value-added to enable the client to seek redress. The General Strain theory perspectives denotes that when clients experience organisational processes being inconsistent would lead to frustration, fear, anger even crime, however, interpersonal behaviour proficiency of the social worker was amiably utilised here.

\subsection{Case Study Narration: Implementing Interactional Justice to Code of Ethics Amid Social Justice and Human Rights Violation}

$>$ A case pertaining to widowhood rights and inheritance at (Owerri zone) involving a widow accused of not participating in the cultural rituals for the dead husband, therefore being accused of killing him and refusing to hand their grandson to them. The family of the deceased husband chase her out of the matrimonial home, burn her properties and want to take away her son but to allow her take her daughter.

Followings were responses gleaned from the senior social workers who administrated the case:

"We allowed each parties to state their issues, taking enough time to record each detailed information, demographic data, marriage concerns, widow's plights, children upbringing and needs...consult the relevant policies, Acts and Gazettes and most vital the NASW Code of Ethics applicable to the country's situation on social justice."

"We make sure we pay home visit to their communities for profiling to get added information to the case...reports to our superiors, hold consultative meetings with community leaders and customary courts officials to ensure social justice 
awareness and the implications of their judgments....these procedures are required by the Ethical Code." "Most of the time, the customary courts officials hold on to their judgments, because of the high patriarchal society we have here in Imo State"... we ensure that this widow get justice by helping her file court papers in the Magistrate and High courts and follow the progress of the case....some cases have gone even to the Appeal and Supreme courts pending ruling."

In application of interactional justice, the respondents apparently utilise time to gather the needed facts of the problem from both parties, connect with the oppressed client and reflect on the plan of action and follow it up, employ interpersonal relationship to create atmosphere of empathy, warmth and compassion for their clients. The social exchange theory on relationship-oriented can be visible as the practitioners engage in quality time expanding their interactional justice implementation and interpersonal skills by using systematic and resolute approach in protecting, representing and advancing the best interest of the clients, use of self-reflexivity to comprehend arrangements of power and obstacle that preserve injustices" (Hoefer, 2006:8; Jonsson, 2010:404).

\section{Discussions of Findings}

The NASW Code of Ethics (2008, Sections 6.01) specified that "social workers should advocate for fulfillment of basic human needs in realization of social justice by their promotion of social, economic, political, cultural values and attuned institutions that will aid in such realization." Furthermore, the Code (Section, $3.09 \mathrm{c}$, d, and $2.09 \mathrm{a}, \mathrm{b}$ ) specify that practitioners should advocate for good ethical practice within their working organisations in adherence and ensure that people were served with efficient and effective adeptly. Dolgoff et al (2010: 187) discussed the need to prioritise needy ones through the empowerment techniques and volunteerism. In the recommendation of creation of mobile day, for each community and designation of a social worker in each ward by participants has correlation with Brown and Green (2009) endorsement that a staff member can be trained in knowledge base of the locality aimed at robust theoretical and conceptual capability, thereby gaining specialty, such that the practitioner would be an asset to the community and service organisation. These findings from these studies correlate with this study's definitions on social justice application to ensure equality by respondents.

The absence of family courts in rural areas of Imo State has led to customary courts steering cases meant to be controlled by family courts and dearth of well trained professionals to handle such sensitive case must have a demoralizing effect on social workers and blockade actualising the social justice ethic implementation. In application of interactional justice, the respondents said that they utilize time to gather the needed facts of the problem from both parties, respect and dignify the worth of any client, connect with the oppressed client and reflect on the plan of action and follow it up, employ interpersonal relationship.

The issues around distributive justice, procedural and organisational injustice can affect the social worker and his clients if the processes are flawed (Agnew, 2006; Colquitt et al, 2005). Interactional justice on its own expresses the ideas that practitioner handling of concerns of the clients must respect the dignity and worth of the person (Scheuerman, 2013). Furthermore, Hoefer (2006:8) backed practitioners in "social justice advocacy to use methodical and focused technique towards protection, representing progressively for the plight of clients' systems."

The application of interactional justice within the social justice ethic authorize for expectation of roles in social exchange, that includes values inherent in socio-emotive, employing respect, worth, dignity irrespective of the status of the interacts, where attention, empathetic skills are utilised (Cropanzano et al, 2001; Clemmer \& Schneider, 1996). The researcher holds the view that accessibility and speed can be collaborated to facilitate action plan, a popular saying "justice delayed is justice denied," validated that interactional injustice can lead to crime (Scheuerman, 2013; Agnew, 2006). They conversely affirm that 'it depends on the deleterious feelings of anger, frustration, fear and depression that might have occurred when strain is experienced.'

The interactional justice emphasis is on the worth of interpersonal behaviour that a person may experience when organisational processes are sanctioned (Colquitt et al, 2001 cited in Scheuerman, 2013). As such practitioners must ensure respect and treat clients with sincerity and dignity and should be non-judgmental (propriety) while maintenance of interactional fairness by being polite and desist from asking inappropriate questions, whereas interactional injustice can evolve, if clients are ignored about their concerns on policy enactment (Colquitt et al, 2005). All these procedures must complement boundary maintenance by practitioners.

In entirety, tackling the vignette, social workers should insightfully evaluate the recommendations therein in the Imo State of Nigeria Widows Protection Law (2003, Section 3 on Prohibition of Obnoxious Practices and section 4 on Dispossession of property) and the Gender Equity Law (2007, Section 20b and 23a) in addressing the uncongenial 
situation.

\section{Recommendations}

Interactional justice advocacy within the social justice ethic is a sure way to address the social and cultural discrepancies that have bedeviled the patriarchal societies in Africa, most especially in South-Eastern part of Nigeria. It is satirical to note that Imo State as one of the leading states in Nigeria in educational attainment of its citizens with the highest literacy in English (National Literacy Survey, 2010:8) will be caged in such obnoxious cultural practices, irrespective of the government efforts in enacting Acts and Laws to liberate societies. Social workers have daunting task to create awareness and be conversant not to be cut in the web of dishing out interactional injustice during engagement with clients in relating to organizational policies or cultural adherence.

The researcher retaliates that practitioners can be well prepared to apply interactional justice in five possible ways.

- "Observe"- through the understanding the issue as it affects their clients by being compassionate and empathic.

- "Connect"- spending/ allowing time with clients not "brief" in view of its "relationship-oriented" and timely visits to appraise the situation. This does not mean allowing unnecessary delays in the prosecuting of perpetrators as accessibility to get redress and promptness are essential. Boundary maintenance is essential here.

- "Reflect'- social workers have to engage in a self-reflective and reflexive practice approach to actualize their aims, goals and objectives to each case, applying social justice ethic as a way of life and consulting documentations on Acts, Laws etc. and self-scrutiny to aid them.

- "Action Plan"- they must have an action plan for each social justice case to be engaged and seek ways to remove cultural generalisations of norms and values that are detrimental to social justice ethic.

- "Be realistic about expectations"- means weighing client's options and dispositions and saying no to hasty conclusion or being pessimistic about change. Practitioners need not create intention to approach social justice ethic with marketing perspective of ephemeral results.

In summary, resolving interactional injustice can be achieved by adopting the need for practitioners to comprehend its application with sincere love for clients' situation not only as duty-bound to revitalize the core humanitarian value of Social work. Nevertheless, the challenging circumstances in this period of trimming management, practitioners should focus more on relationship building blended with compassion, empathy and love with optimistic professionalism. Further research should engage on administrators-practitioners outcome on interactional justice within the practice settings to investigate the gaps in implementing policy regulations that might encroach on social justice ethical code adherence. Research on Social work ethical code on social justice should incorporate the three justices' outcome including its boundary maintenance effects during practice.

\section{References}

Afigbo, A. E. (1989). Widowhood Practices in Africa; A preliminary Survey and Analysis. Paper presented at the Workshop "Widowhood Practices in Imo-State". Owerri, June 6-7.

Agnew, R. (2006). Pressured into crime: An overview of General Strain Theory. Los Angeles, CA: Roxbury Publishing Company.

Aryee, S., Budhwar, P.S. \& Chen, Z. X. (2002). Trust as a mediator of the relationship between organisational justice and work outcomes: Test of a social Exchange Model. Journal of Organisational Behaviour. 23: 267-285.

Bankston, C. L., III (2010). Social justice: origins of a perspective and a theory. Independent Review, 15 (2).

Blau, P. (1964). Exchange and Power in Social Life. Wiley: New York.

Blodgett, J. G., Hill, D. J., \& Tax, S. S. (1997). The effects of distributive, procedural, and interactional justice on post complaint behavior. Journal of Retailing, 73, 185-210.

Brown, G. \& Green, R. (2009). Ensuring the Future of Rural Social Work in Australia. Rural society, 19 (40):293-295.

Buila, S. (2010).The NASW Code of Ethics under Attack: A Manifestation of The Culture War within the Profession of Social Work. Social Work Values and Ethics, 7 (2), fall 2010.

Calma, T., Baldry, E., Briskman, L. and Disney, J. (2011). What is Social Justice? Occasional Paper \#1, National Pro Bono Resource Centre. October, 2011. Available at https://wic041u.server-secure.com/.../Occ_1_What\%20is\% 20Social\%20J [Retrieved on 18 104 / 2012].

Clayton, M., \& Williams, A. (2004). Social justice. Wiley-Blackwell.

Clemmer, E. C., \& Schneider, B. (1996). Fair service. In T. A. Swartz, D. E. Bowen, \& S. W. Brown (Eds.), Advances in services marketing and management (Vol. 5, pp. 109-126). Greenwich, CT: JAI Press.

Colquitt, J. A., Greenberg, J., \& Zapata-Phelan, C. P. (2005). What is organizational justice? A Historical Overview. In J. Greenberg, \& J. A. Colquitt (Eds.), Handbook of organizational justice (pp. 3-56). Mahwah, NJ: Lawrence Erlbaum Associates, Inc. 
Colquitt, J. A., Conlon, D. E., Wesson, M. J., Porter, C.O. L. H., \& Yee Ng, K. (2001). Justice at the millennium: A meta-analytic review of 25 years of organizational justice research. Journal of Applied Psychology, 86, 425-445.

Colquitt, J. A. (2001). On the dimensionality of organizational justice: A construct validation of a measure. Journal of Applied Psychology, $86,386-400$.

Creswell, J. W. (2009). Research design: Qualitative, quantitative, and mixed methods approach. London: Sage Cropanzano, R., Rupp, D. E., Mohler, C. J., \& Schminke, M. (2001). Three roads to organizational justice. In G. R. Ferris (Ed.), Research in personnel and human resources management (Vol. 20, pp. 1-113). New York: JAl Press.

Cropanzano, R., Mitchell, M. S. (2005). Social exchange theory: An interdisciplinary review Journal of Management, 31, 874-900.

Dolgoff, R., Harrington, D. \& Loewenberg, F. (2012). Ethical Decisions for Social Work Practice. 9th Ed. International Edition. Brooks/Cole, Cengage Learning.

Farrington, J., \& Farrington, C. (2005). Rural accessibility, social inclusion and social justice: towards conceptualization. Journal of Transport Geography, 13, (1): 1-12.

Federal Republic of Nigeria (2006). National Gender Policy. Federal Ministry of Women Affairs and Social Development. Federal Secretariat Complex, Maitama-Abuja.

Forde, C., \& Lynch, D. (2013). Critical Practice for Challenging Times: Social Workers'

Engagement with Community Work. British Journal of Social Work (2013):1-17. doi:10.1093/bjsw/bct091

Glass, R. S., \& Wood, W. A. (1996). Situational Determinants of Software Piracy. An Equity Theory Perspective. Journal of Business Ethics, 15(11):1189-1198.

Gross, K., Alba, S., Glass, T. R, Armstrong Schellenberg, J., \& Obrist, B. (2012). Timing of

Antenatal Care for adolescent and adult women in South-East Tanzania. BMC Pregnancy \& Childbirth, 2 (16). DOI:10.1186/1471-239312-16. Available at http://www.biomedcentral.com [Retrieved on 30/01/2014].

Greenberg, J. (1990). Organizational justice: Yesterday, today, and tomorrow. Journal of Management, 16 (2), 399-432.

Greenberg, J. (2010). Insidious workplace behavior. New York, NY: Routledge.

Hajer, M. A. (2005). Setting the Stage: A Dramaturgy of Policy Deliberation. Administration \& Society, 36, 6: 624-647. DOI: 10.1177/0095399704270586@ 2005 Sage Publications.

Hoefer, R. (2006). Advocacy practice for social justice. Chicago, IL: Lyceum Books, Inc.

International Labour Organisation (ILO) Declaration on Social Justice for a Fair Globalization. Adopted by the International Labour Conference at its Ninety-seventh Session, Geneva, 10 June 2008. Available at http://www.ilo.org/wcmsp5/groups/public/--dgreports/---cabinet/document [Retrieved on 16/11/2013].

Imo State of Nigeria. Gender and Equal Opportunity Law No.7 (2007). Gender and Equity. The Women Affairs Department, Ministry of Women Affairs \& Social Development, Owerri, Imo State.

Imo State of Nigeria. Widows Protection Law No.12 (2003). Give the Widow Her Rights. The Women Affairs Department, Ministry of Women Affairs \& Social Development, Owerri, Imo State.

Jonsson, J. H. (2010). Beyond Empowerment: Changing Local Communities. International Social Work, 53(3):393-406.

Kang'ethe, S. (2011). The role of incentives in raising care-giving productivity in Botswana Care Programmes as exemplified in the Kanye Care Programme. Social Work/Maatskaplike Werk, 47(1):59-72.

Ladebo, O, J., Awotunde, J. M. \& Abdulsalaam-Saghir, P. (2008). Coworkers' and Supervisor Interactional Justice: Correlates of Extension Personnel's Job Satisfaction, Distress, and Aggressive Behavior. University of Agriculture, Abeokuta, Nigeria. Available at http://www.ibam.com/pubs/jbam/articles/vol9/no2/JBAM_9_2_6.pdf [Retrieved on 21/05/2014].

Larson, R. (1987). Perspectives on queues: Social justice and the Psychology of queuing. Operations Research, 35(6), 895905.

Marti'Nez-Tur, V., Peiro, J. M., Ramos, J., \& Moliner, C. (2006). Justice Perceptions as Predictors of Customer Satisfaction: The Impact of Distributive, Procedural, and Interactional Justice. Journal of Applied Social Psychology, 2006, 36, (1):100-119. ( 2006 Blackwell Publishing, Inc.

National Association of Social Workers (NASW, 2008) Code of Ethics. Available at http://www.sp2.upenn.edu/docs/resources/nasw_ code_of_ethics.pdf_[Retrieved on 27/06/2011].

National Bureau of Statistics of Nigeria. (2007). Available at www.nigeriastat.gov.ng [Retrieved on 15/03/2014].

National Literature Survey (2010). National Bureau of Statistics. Media \& Marketing

Communications Company Group National Commission for Mass Literacy, Adult and Non Formal Education. Available at www.nigerianstat.gov.ng [Retrieved on 11/04/2014].

Neuman, W. L. (2006). Basics of Social research Methods: Qualitative and Quantitative Approaches (2Ed). Boston: Allyn \& Bacon.

Oliver, R. L., \& Swan, J. E. (1989a). Consumer perceptions of interpersonal equity and satisfaction in transactions: A field survey approach. Journal of Marketing, 53, 21-35.

Oliver, R. L., \& Swan, J. E. (1989b). Equity and disconfirmation perceptions as influences on merchant and product satisfaction. Journal of Consumer Research, 16, 372-383.

Rawls, J. (1971). A theory of justice. Cambridge: Belknap Press of Harvard University Press.

Richter, M.S. and Mlambo, G.T. (2005). Perceptions of rural teenagers on teen pregnancy.

Health SA Gesondheid. 10, (2). Available at www.thefreelibrary.com Health SA Gesondheid > June 1, 2005. [Retrieved on 09/03/2014].

Rodgers, J. A. (2009). Global Social Work Practice, Human Rights, Social Work Ethics and

Human Responsibilities: The Challenge. Journal of Global Social Work Practice, 2, No 2, November/December 2009. Available at http://www.globalsocialwork.org [Retrieved on 18/09/2013]. 
SACSSP (South African Council of Social Service Professions, 2005). Policy Guidelines for Course of Conduct, Code of Ethics and the Rules for Social Workers. Available at http://www.sacssp.co.za [Retrieved on 23/07/2011].

Scheuerman, H. L. (2013). The relationship between injustice and crime: A general strain theory approach. Journal of Criminal Justice, 41 (2013) 375-385. Available at www.ScienceDirect.com [Retrieved on 18/09/2013].

Simmons, C. \& Rycraft, J. (2010). Ethical challenges of Military Social workers in a combat zone. Social Work, 55:9-18.

Soini, K. \& Birkeland, I. (2014). Exploring the Scientific discourse on cultural sustainability. Geoforum, 51:213-223.

Stecher, M. D. \& Rosse, J. (2005). The distributive side of interactional justice: The effects of interpersonal treatment on emotional arousal. Journal of Managerial Issues, 17(2): 229- 246.

Thibaut, J., \& Walker, L. (1975). Procedural Justice: A Psychological Analysis. Lawrence Erlbaum Associates, Hillsdale, NJ.

Vallace, S., Perking, H. C., \& Dixon, J. E. (2011). What is social sustainability? A clarification of concepts. Geoforum, 42 (3): $342-348$. Doi 10.1016/j.geoforum.2011.01.002.

Vandervort, F. E., González, R. P., \& Faller, K. C. (2008). Legal Ethics and High Child Welfare Worker turnover: An Unexplored Connection. Children and Youth Services Review, 30(2008):546-563.

Ward, T., \& Birgden, A. (2007). Human Rights and Correctional Clinical Practice. Aggression and Violent Behaviour, 12 (6):628-643, Elsevier Science, New York, N.Y. ERA journal ID: 6066 - Scopus EID: 2-s2.0-34848832391.

Wayne, S. J., Shore, L. M. \& Liden, R.C. (1997). Perceived organisational support and leader-member exchange: a social exchange perspective. Academy of Management Journal, 40: 82-111.

World Day of Social Justice celebration on the 20th February, 2013 by the United Nations. Available at http://www.un.org/en/events/ socialjusticeday/ [Retrieved on 16/11/2013].

Young, I. M. (2006). Responsibility and Global Justice: A Social Connection Model. Social Philosophy and Policy, 23 (1):102-130.

Zajda, J., Majhanovich, S., \& Rust, V. (2006). Education and Social Justice. Springer Verlag. 